\title{
Distribution of beach litter along the coastline of Cádiz, Spain
}

\begin{abstract}
A total of 59 categories of litter items were found at 20 beaches (13 mechanically cleaned, 7 non-cleaned) in the Cádiz tourist environment, Spain. Cluster Analysis and Principal Components Analysis were used to highlight similarities and contrasts between sites and/or associations between litter categories. Multivariate analyses separated beaches according to the total numbers of litter items present. Non-cleaned sites showed a variety of litter category abundance with distinct origins and abundant, ubiquitous items (plastic and glass fragments). Of the 7 non-cleaned beaches (49 litter categories) river-mouth sites were distinct due with high numbers of litter items The sheltered inner part of Cádiz Bay beaches had a wide range of litter type. Many sites were associated with locally deposited recreational litter categories; whilst industrial/commercial/fishing categories were abundant only at a few sites, indicating items transported onto the shore from the Guadalete river.
\end{abstract}

KEY WORDS: Beach grading, Cluster Analysis, Principal Component Analysis, tourism, coastal management, morpho-dynamic beach state.

\section{INTRODUCTION}

Some 1,138 million global international tourists were recorded in 2014 with Spain having 61 million visitors, who brought in some US\$ 60 billion, the second largest country tourist income worldwide and the biggest in Europe (UNWTO, 2015). Visitors are especially interested in coastal tourism and it is one of the world's largest industries (Klein et al., 2004), with beaches being a major factor in this market (Houston, 2013). For Europe, Spain plus Italy, France, Greece and Turkey account for 'the most significant flow of tourists . . . a sun, sea and sand (3S) market’' (Dodds and Kelman, 2008).

Marine debris (solid waste materials) and litter (discarded man-made objects) together with micro-plastics ( $<5 \mathrm{~mm}$ in size) are ubiquitous in the world's oceans and beaches, negatively affecting these, the economy, wildlife and human health (Cheshire et al., 2009; UNEP, 2012). Land-based sources comprise circa $80 \%$ of the litter of which some $50-80 \%$ is plastic (Taffs and Cullen, 2005; Martinez-Ribes et al., 2007; Barnes et al., 2009; Hong et al., 
2014) and on UK beaches this has increased by some 140\% since 1994 (MCS, 2013). Marine litter is not only observed on beaches (Velander and Mocogni, 1998; Santos et al., 2009) but also in the pelagic and benthic zones (Galgani et al., 2000; Thiel et al., 2011). This not only creates aesthetic and related economic problems (Smith et al., 1997), but also has important negative effects on biota and the ecosystem because of the ingestion of micro and mesoplastics by animals (van Franeker et al., 2011; Browne et al., 2011) together with entanglement of animals in abandoned nets, fishing lines, ropes and ribbons (Gregory, 2009; Votier et al., 2011). Marine litter also impacts on non-market scenic values. On beaches the negative effects relate to potentially hazardous and unsightly items, e.g. sanitary and medical waste, which damage local and tourists perception of a resort. This is reflected in tourist days lost, which results in economic loss (Philipp, 1993; Tudor and Williams, 2004). For example, in New Jersey, USA in 1987, and Long Island, in 1988, an estimated loss of between 37 and 121 million user days at the beach and between US\$1.3 and 5.4 billion in tourism-related expenditure was attributed to the presence of syringes, vials and plastic catheters along the coastline (Valle-Levinson and Swanson, 1991).

Beach cleaning operations are the main tool for ensuring litter free beaches, and these are often mandatory and costly. For example, in 1993, \$1.4 million was spent cleaning the Bohuslan coast of Sweden (Olin, 1994); >\$1 million was spent in 1988 and 1989 cleaning up the coasts of Santa Monica and Long Beach in California (Kauffman and Brown, 1991); UK municipalities spend approximately $€ 18$ million/year removing beach litter; some $€ 10.4$ million/year are spent in the Netherlands and Belgium (Mouat et al., 2010). Ariza et al. (2008a) investigated the annual declared (public) investment on beach maintenance, cleaning and conservation by each of the 38 municipalities along the $430 \mathrm{~km}$ of Catalonian coast (NE Spanish Mediterranean). The average annual cost per beach, which did not include sand management operations directly carried out and funded by the Spanish government, was $€$ 133,113 , with a wide range from $€ 7,000$ to $€ 845,820$. In the Cádiz municipality, which hosts several tourist beaches, the amount invested in 2014 in beach cleanliness and maintenance of infrastructures was $€ 1,200,000$. Cleaning is expected at resort/urban beaches; whilst at rural and remote sites it appears not to be obligatory.

Public health implications may arise from coastal litter accumulations, such as, injuries caused by marine debris including net entanglement of scuba divers (Cottingham, 1989), cuts caused by broken glass and discarded ring tabs from cans, broken and/or rusted cans and other cutting items (Whitting, 1998), skin punctures from abandoned syringes 
(Dixon, 1981) and exposure to chemicals from leaking containers washed ashore (Dixon and Dixon, 1981). Less evident health risks are linked to diseases (among them Hepatitis B and Human Immunodeficiency Virus HIV; Walker, 1991) caused by potential ingestion or contact with blood or other body fluids contained in sewage residual debris and medical waste. Philipp (1991) associated microbiological hazards with other visible pollutants, such as discarded food, dead animals, oil, containers and tyres, and observed that the presence of litter is likely to be accompanied by high counts of the bacterium Escherichia coli, and with gastro-intestinal illness after sea bathing (University of Surrey, 1987).

The research objectives of this paper were to highlight similarities/dis-similarities in litter content among investigated beaches in the Cádiz area of Spain according to their visitor use, cleaning operations, morpho-dynamic beach state, closeness to a river or tidal creek mouth and level of exposure. Very few such surveys have been reported for Spain and studies published in international journals invariably relate to the Mediterranean rather than the Atlantic coastline, e.g. Gabrielides et al. (1991), Ariza et al. (2008b) and Roca et al. (2009). For the Atlantic side of Andalusia, a few limited observations have been carried out within the CoastWatch program (Jurado et al., 2006; Corral et al., 2007 and unpublished reports).

Public beach cleaning events can educate participants about litter but are usually carried out by a 'converted' audience and do not address the issues of prevention at source, as it is the links to sources that present the main challenge. The main driver for beach cleans seemingly is the economic impact on coastal tourism, as litter strewn beaches negatively affect tourism (Ofiara, 2001; Mcllgorm et al., 2011; Williams et al., 2016). A first step in assessing the litter problem is to establish appropriate monitoring surveys. Many guides exist covering survey design (Cochran, 1977; Ribic et al., 1992; Earll, 1996). Investigations may be simple enumeration studies, e.g. assessing types and litter quantities, or in greater detail adding age/origin of items. They can cover large geographical areas such as the CoastWatch Europe network (Dubsky, 1995) and the Tidy Britain Group in the UK (Dixon and Hawksley, 1980; Dixon and Dixon, 1981) or relate to detailed information of specific regions/places (Williams and Simmons, 1997). For example, in Chatham County (Georgia, USA), Gilligan et al. (1992) chose four site types to investigate tidal influence on beach litter composition; Ariza et al. (2008b) and Lopes da Silva et al. (2015) investigated seasonal changes in beach litter at selected sites along the coast of Spain and Brazil, respectively. According to the scale of investigation, obtained results are very useful to local or national coastal managers and planners, who need coastal, landscape inventories based on ascertained facts in order to make 
sound management decisions. Surveys reported in this paper provided a first step in the characterization of beach litter at different areas along the Cádiz, Andalusia, South-west Spain coastal area.

\section{MATERIALS AND METHODS}

\subsection{Location}

The investigated area includes 20 beaches located along $80 \mathrm{~km}$ of coastline around Cádiz town, on the Atlantic side of Andalusia (South-west Spain, Fig. 1). Cádiz province is a densely populated area with 1,207,343 inhabitants, i.e. $15 \%$ of the Andalusia Province and $2.7 \%$ of the whole of Spain. In 2014, it recorded 2,092,818 stay-night visitors, two thirds being national and one third international visitors (www.andalucia), essentially interested in coastal tourism because of the good weather conditions that makes it possible for bathing during several months of the year (Williams et al., 2012).

The coast lies predominantly in a northwest-southeast orientation, has a mesotidal range, mean values of neap and spring tides of 1.0 and $3.5 \mathrm{~m}$, respectively. It is characterized by a diversity of coastal landforms and environments including sand spits, quartz-rich sand beaches, dunes, saltmarshes, cliffs and rocky shore platforms (Anfuso and Gracia, 2005; Rangel Buitrago and Anfuso, 2011, 2013). Two important tidal creeks, namely San Pedro and Sancti Petri, are located in the central and southern part of investigated coast (Fig. 1) but the important watercourses flowing into the coast are:

- the Guadalquivir River, 657 kilometres in length, which passes through Córdoba and Seville and,

- $\quad$ the Guadalete river, 172 kilometres long.

The area is affected by westerly and easterly winds. Westerly winds are related to Atlantic low pressure systems that can continue for several days and affect large areas of the Iberian Peninsula. Winds blowing from E to SE directions are originally formed in the Mediterranean Sea and greatly increase in velocity due to channelling through the Gibraltar Strait. Due to coastline orientation, westerly winds give rise to both sea and swell waves, while easterly winds have no significant fetch and mainly give rise to sea waves. The main longshore drift flows south-eastward but occasionally an opposite transport flow can be recorded (Rangel Buitrago and Anfuso, 2011 and 2013). 
The most important coastal towns are Sanlúcar, Chipiona, Rota, El Puerto de Santa María, Cádiz and San Fernando (Fig. 1). They have recorded an impressive spatial expansion in past decades and currently the coastal population along the area reaches 500,000 inhabitants which doubles during the summer period. Despite the high levels of population and developments, certain areas have been conserved intact because they belong to the 'The Bay of Cádiz' Natural Park which has an area of 10,522 ha and includes large areas of wetlands, beaches, dunes and salt harvesting areas. Investigated beaches include urban, residential and natural areas, and all have high or very high tourist relevance linked to the ' 3 S’ market.

\subsection{Beach characteristics}

Beaches were categorized according to their level of exposure to wave energy based on their location on open, exposed coasts or in sheltered areas, such as, bays and estuaries. The closeness to a river mouth or a tidal inlet (Ariza et al., 2008b), can affect the characteristics of beach litter because of the accumulation of river-born litter (Dixon and Dixon, 1981).

The morpho-dynamic state of the foreshore was evaluated visually, distinguishing between:

- $\quad$ dissipative conditions, e.g. flat beaches composed of fine sand;

- intermediate conditions, e.g. beaches with intermediate slope values and composed of medium-coarse sand, and

- $\quad$ reflective conditions, e.g. a beach with a low tide terrace and a relatively steep upper foreshore (Wright and Short, 1984; Masselink and Short, 1993; Anfuso and Gracia, 2005).

Regular beach cleaning operations were carried out by local authorities at several of the selected beaches. The following sites were not routinely cleaned, or had not yet been cleaned at the time of the survey: Sanlúcar norte, Sanlúcar sur, Costa Ballena, Rota, Valdelagrana río, Puerto Real and Camposoto río (Fig. 1). Urban beaches were usually cleaned manually and mechanically daily throughout the year. Cleaning machines had a mesh size of $2 \mathrm{~cm}$, enabling some but not all cigarette ends to be picked up, as currently the efficiency of mechanical cleaning is low (Ariza et al., 2008b). Unfortunately cleaning machines were not able to move close to walls and pathways so items accumulated there 
were not collected. Beaches located in residential and natural areas are usually mechanically cleaned each day during June to September and with an approximately weekly/monthly frequency in April/May and in October/November but no cleaning operations were normally carried out in winter time (December to March).

\subsection{Beach surveys}

Surveys were carried out at low tide at 20 beaches during the period April 19-27, 2014 and all litter items found between the low water strandline to the landward boundary, usually dunes or a seawall, on a beach transect width of 50m either side from a beach access point, i.e. a 100m width transect, were recorded (EA/NALG, 2000). This survey encompasses $>90 \%$ of the beach litter available (Williams and Tudor, 2010). The low water strandline together with the landward boundary are the main beach litter nodal points, as away from recreational beaches, litter found between these points constitute $<2 \%$ of beach litter (Williams et al., 2014). This methodology enables a beach to be graded on a scale "excellent" to "poor" (grades A to D respectively, Table 2) and informs beach managers of the severity of litter impact at a beach site. The beach takes on the score of the lowest grade scored in any of the 7 categories shown in Table 2, e.g. if any one category scored $\mathrm{D}$, the beach is graded $\mathrm{D}$ overall.

Site selection was based on a uniform geographic spread of beaches along the Cádiz coast in order to include different environments (urban to natural) and not because they were known to be heavily polluted, or subject to specific types of pollution. Based on previous work (Jurado et al., 2006) and exploratory field visits, a list of 183 categories of litter was compiled according to their material composition (Dixon and Dixon, 1983) and size (Ribic, 1990), of which 59 categories were present among the 20 sites surveyed (Table 1). These categories conformed to the EA/NALG (2000), Cheshire et al. (2009), OSPAR (2009) and NOAA (2012) classifications.

\subsection{Statistical analysis}

A total of 59 categories of litter items were present among the 20 sites sampled (Table 1). These data were subjected to Cluster Analysis and Principal Components Analysis, intended to highlight similarities and contrasts between sites and/or associations between litter categories with respect to their relative abundance at the sites. Of the 20 beaches sampled, the seven sites not affected by frequent mechanical cleaning or not yet cleaned prior to the survey 
(Sanlúcar norte, Sanlúcar sur, Costa Ballena, Rota norte, Valdelagrana río, Puerto Real and Camposoto río; Fig. 1) were re-analysed separately using the 49 litter categories present.

Hierarchical Cluster Analysis (CA) was performed using Ward's method with Squared Euclidean distance, both with and without standardized variables (categories). With non-standardized data, categories are weighted in the analysis by their individual numerical values. Hence those with high abundance at sites have a strong influence on derived clusters relative to those with low occurrences. With standardized data, categories become weighted according to a common mean value; hence those with relatively low and high occurrence contribute equally strongly. Cluster analysis of the categories used correlation coefficients, which implicitly standardizes all variables. Dendrograms were used to illustrate hierarchical relations between both site and category clusters.

Principal Components Analysis (PCA) was performed, with sites as "cases" and categories as "variables", using both Covariance (non-standardizing) and Correlation (standardizing) coefficients. PCs 1 and 2 (which together account for the majority of the variance in the data), were illustrated as scatter-plots (sites) and vector plots (categories). Patterns of distribution of sites on the PC axes were interpreted with reference to the orientation of the corresponding category vectors and additional information such as site location and beach management. Analyses were performed using Minitab 17.

\section{RESULTS}

\subsection{Beach characteristics}

Dissipative conditions were observed in most of the investigated beaches, i.e. 3 Chipiona norte; 4 Chipiona sur; 5 Costa Ballena; 7 Rota centro; 12 Valdelagrana norte; 13 Valdelagrana sur; 14 Valdelagrana río; 15 Puerto Real; 16 Playa de Santa María and 17 Playa Victoria. Intermediate conditions were recorded at 6 Rota norte; 9 El Puerto de Santa María norte; 10 El Puerto de Santa María centro; 11 El Puerto de Santa María sur; 18 Camposoto norte; 19 Camposoto sur and 20 Camposoto río. Reflective conditions were recorded at 1 Sanlúcar norte; 2 Sanlúcar sur and 8 Rota sur.

Sheltered beaches (Fig. 1) were beach sites 1 and 2 Sanlúcar norte and sur (because of coastal orientation, and location at Guadalquivir river mouth); 8 Rota sur (coastal orientation, and location between two harbours); 11 El Puerto de Santa María sur (enclosed by a long 
jetty); 14 Valdelagrana río (within the inner part of Cádiz Bay, at the end of a sand spit at San Pedro tidal creek mouth, confined southward by a reclaimed area armoured by a seawall); 15 Puerto Real (an artificial beach created on a tidal mud-flat within the inner part of Cádiz Bay, with lowest wave energy); 20 Camposoto río (located at Sancti Petri tidal creek mouth and protected by a small rocky island, part of a rock shore platform extending along the area).

\subsection{Beach litter abundance and composition}

In the current surveys, litter items varied widely in abundance, e.g. a maximum count of 24 glass beverage bottles was found at Sanlúcar norte, 0 at Chipiona sur; 23 bottle caps/lids at Sanlúcar sur and 0 at Rota centro. Some categories were widespread among sites, e.g. small/medium pieces of hard/film plastic and foil wrappers occurred at 19, or at all 20 sites, whereas many categories occurred with low frequency, e.g. 19 categories each occurred at only 1 site. The total number of litter items observed per site ranged from 28 items at Chipiona sur to a maximum of 276 at Sanlúcar norte (Fig. 1). Of the total 2,277 litter items found, the most abundant were various hard/film/foamed plastic pieces (total 736; 32\% of all items), foil wrappers (188; 8\%), cigarette stubs (181; 8\%), cleaner bottles (138: 6\%), industrial packaging materials (104; 5\%) and plastic drinking straws (90; 4\%). Major components of the litter were food packaging (foil wrappers, food cans, hard/foamed plastic containers - 310; 14\% of total litter items) and drink containers (metal cans, glass bottles and plastic drink bottles and cups - 123; 5\% of total litter items).

\subsection{Hazardous items: characteristics and distribution}

- $\quad$ Cutting hazard: e.g. glass fragments, broken tin containers/aluminium cans and pieces of metal or wood with nails protruding,

- $\quad$ Potential infection hazard: e.g. discarded food, dead animals, sanitary towels and other feminine hygienic products.

Highest values for hazardous items, specifically glass fragments, were recorded at Sanlúcar norte, Sanlúcar sur, Rota norte (non-cleaned beaches) and Valdelagrana sur (cleaned), whereas at other cleaned beaches (e.g. Playa de Santa María) fewer glass fragments occurred (Table 3). No dead animals, nappies, syringes, or cotton buds were found, but sanitary towel discards occurred at three sites (Rota norte, Valdelagrana río and Valdelagrana sur), and 5 condoms at Chipiona norte, Table 3). Examples of gross litter items, car tyres were found at the river sites of Valdelagrana río and Sanlúcar norte. 


\subsection{Multivariate analyses: cluster analysis (CA) and principal components analysis (PCA) - 59 litter categories at 20 beach sites (Figure 1).}

CA of sites (non-standardized) revealed 2 distinct groups (Fig. 2). Firstly, a group of 6 sites contain the largest total numbers of items per site ("nitems": shown below each site code), comprising three pairs of sites: Sanlúcar norte/Sanlúcar sur; Valdelagrana río/Puerto Real (two pairs which cluster together consistently in all analyses), and Costa Ballena/Rota norte. In the alternative 14-site group, sites contain fewer total litter items. This analysis reflects the presence of numerically large litter categories (e.g. PL62, PL51; Table 1) hence the two opposing clusters clearly indicate "dirty” versus “clean” sites. All sites in the "clean" group, except for Camposoto río, are cleaned daily by machine whereas in the "dirty” group no sites are cleaned. The corresponding PCA (covariance, non-standardized) shows, similarly, a clear trend along the first component (PC1) from sites with largest numbers of litter items on the right, to those with smallest to the left (Fig. 3). On PC2, Valdelagrana río is distinct from other "dirty" sites, as it contains the largest number of PL51 (industrial packaging etc.). The cleaned sites form a distinct group with the exception of Camposoto río, which lies close to two cleaned sites, but has fewer total litter items (Fig. 3). Similar patterns resulted from standardized CA and PCA (not shown here), despite all litter categories being equally weighted in these methods. This suggests that the distribution of litter categories between sites provides a consistent discrimination between relatively "dirty" and "clean" beaches.

PCA for litter categories (covariance, non-standardized; Fig. 4), highlights numerically large categories which achieve distinct locations on the principal axes (i.e. longer vectors from the origin) and hence these determine the corresponding axis positions for the sites (Fig. 3). Categories PL62/PL63/PL07 (abundant plastic items) lie at the positive pole of PC1, related to generally dirty sites, whereas PC2 places PL51 (industrial packaging; Table 1) in contrast to PL24/ME09/PL18 (cigarette stubs, foil wrappers, plastic straws). Standardized PCA again highlights the same categories (Fig. 5), but with many additional prominent category vectors reflecting their relative distributions among the sites. For example, categories PL65/PL66/ME04/GL01 (plastic film pieces, drink cans, beverage bottles, Table 1) also occupy the positive pole of PC1, whereas PL11/ME24/PL45 (large oil containers, large metal pieces, fish boxes, Table 1) orientate on PC2 with PL51 (industrial packaging) in opposition to ME10/PP04/PL24 (food cans, cigarette packets and stubs, Table 1). Hence the pattern is similar to that of Fig. 4, but with many categories achieving equally 
prominent axis positions. Standardized CA for the categories (not shown) produced cluster groups which reflect the relative positions of the major category vectors as described above for PCA (Fig. 5), with additional groups of categories of low occurrence.

\subsection{Multivariate analyses: cluster analysis (CA) and principal components analysis (PCA) - 49 litter categories at 7 beach sites not subject to cleaning management}

\section{(Figure 1; Table 4).}

CA (non-standardized) of non-cleaned sites clustered the two northerly sites containing the largest total numbers of litter items (Sanlúcar norte and sur), and the five remaining sites separate further according to total number of items present (Fig. 6). The corresponding PCA similarly displays a trend (on PC1) from high to low total items (Fig. 7) but shows Valdelagrana río to be distinct on PC2. Similar patterns emerge with standardized CA and PCA (not shown here).

PCA for litter categories (non-standardized) highlights the few numerically large categories occurring on the non-cleaned beaches (Fig. 8), whereas in the standardized PCA many more categories appear as prominent vectors due to their equal numerical weighting (Fig. 9). In both analyses, PC1 contrasts a variety of litter categories, e.g. PL24/GL01/GL09/ME04/PL62/PL63 (cigarette stubs, glass bottles and pieces, drink cans, hard plastic pieces; Table 1) versus PL42/PL46 (rope, angling line; Table 1), whereas PC2 contrasts PL51 (industrial packaging; Table 1) versus PL70 (large foam-plastic pieces). Similar to the analysis of all 20 sites (Fig. 5), PC2 appears to contrast PL16/PL18/ME10/ME09 (plastic knives/forks/straws, food cans, foil wrappers; Table 1) versus ME24/PL51/PL11/PL45/PP09/WO13 (large metal pieces, industrial packaging, large oil container, fish box, drink carton, small wood pieces; Fig. 9). Similar associations of categories were seen in the CA category clusters (not shown).

\section{DISCUSSION}

\subsection{Origins}

Litter item origins at any site are complex; e.g. food containers or cigarette stubs could be discarded locally or transported down-river, whilst plastic pieces could have either industrial or domestic origins. On the other hand, large oil containers and fish boxes are likely to be transported onto site. Items that float readily (wood, foam plastic) could originate at a distance in the marine environment. Hence the patterns emerging from these analyses do 
not reflect in a simple way the origins or modes of deposition of litter categories sampled at the seven non-cleaned beach sites.

\subsection{Litter categories at all sites}

Various plastic items were highly abundant on all beaches surveyed, in agreement with beach litter pollution described by OSPAR (2009) and Schulz et al. (2013). Plastic fragments, bags and plastic sheeting also represent the most frequently occurring items at many UK localities (Williams and Simmons, 1997). These findings also confirm many studies which have shown that plastics, especially plastic bottles, constitute most of marine and beach debris (Dixon and Dixon, 1983). In a survey of 13 beaches in Spain, Italy (Sicily), Turkey, Cyprus and Israel, Gabrielides et al. (1991) observed as plastic items, such as fragments $(<5 \mathrm{~cm})$, sheeting $(<10 \mathrm{~cm})$ and water bottles were the most abundant litter components, followed by cigarette stubs and cans (non-alcoholic beverages). Glass pieces were also abundant at several beaches, as was the case in Cádiz. Woodall (1993) and Whiting (1998) found that on Australian beaches, synthetic products (plastic, rubber and foam) accounted for $45 \%$ of total items collected while metal and glass accounted for $35 \%$ and $15.6 \%$, respectively. Locally, the current survey confirmed results of previous CoastWatch surveys (unpublished) carried out in October-November 2008 at the same beach sites. Volunteers counted the number of recognizable containers of different materials along the whole length of investigated beaches, so the total numbers of items recorded in 2008 were much larger than in this study. Plastic bottles/containers were the most frequent $(2,545)$ items followed by plastic bags (1,766), metal containers (932), paper tetra-packs (655), glass bottles/containers (508), PVC containers (158) and tyres (35), whereas in this study, tyres were recorded only at Sanlúcar, at the Guadalquivir river mouth.

\subsection{Beaches with clean-ups}

Surveys showed clearly that beach cleaning operations carried out at 13 locations have a major impact on the overall state of the beach. All of the multivariate analyses discriminate sites on this basis and highlight differences in the distribution of litter categories between the sites. Beach cleaning operations affect the results of beach-litter surveys in different ways according to frequencies and operational modalities (Somerville et al., 2003; Moore et al., 2001; Velander and Mocogni, 1998). Despite the abundance and variety of litter items found in this survey, according to the EA/NALG (2000) grading system, it appears that many beaches are in a relatively acceptable state (Tables 4 and 5). All except one of the cleaned 
beaches achieved grade B (site 4, Chipiona sur, had a C), whereas 6 of the 7 non-cleaned sites were grade $\mathrm{C}$ due to general litter/broken glass and mixed litter accumulations (site 14, Valdelagrana río, achieving a B grade, Tables 3, 4, 5). This suggests that beach grading could be improved by relatively little additional cleaning operations. For example Playa Victoria (site 17), an important recreational beach, scored B only for the gross litter category (fish boxes) and individual large items of this kind could be easily removed.

\subsection{Beaches with no clean-ups}

Analysis of the seven non-cleaned beach sites (Figs. 6, 7; Table 1), again shows no simple geographical trend, but separates the two most northerly sites Sanlúcar norte and Sanlúcar sur which are located at the mouth of a major river, Guadalquivir, known to be the source of a variety of water-borne litter items. Valdelagrana río and Puerto Real beaches, also with large numbers of litter items, act as accumulation areas for items transported to, or discharged within the Bay of Cádiz (Fig. 1). Valdelagrana río site, close to a tidal creek, accumulates water-borne litter entering the Bay from the Guadalete river and moved southward by wind and wave action. Similarly, Camposoto río, in the shelter of a rocky platform, accumulates litter originating elsewhere. Such sheltered accumulation zones may be linked to litter sources from rivers, longshore transport or tidal currents (Álvarez et al., 1999).

In these analyses of the solely non-cleaned beach sites (Figs. 8, 9), the orientation of category vectors on PC1 appears to show a contrast between categories of recreational origin deposited by visitors in situ, e.g. PL24/GL01/GL09/ME04/PL62/PL63 (cigarette stubs, glass bottles and pieces, drink cans, hard plastic pieces; Table 1), versus those transported onto the site but originating elsewhere, e.g. PL42/PL46/PL51/PL70 (rope, angling line, industrial packaging, large foam plastic pieces; Table 1). PC2 highlights categories of industrial or commercial origin e.g. PL51/PL11/PL45/PL62/PL63/PL07 (industrial packaging, large oil containers, fish boxes, hard plastic pieces, cleaner bottles; Table 1), versus items discarded after eating, e.g. ME09/ME10/PL19/PL24 (food cans, foil wrappers, food containers, cigarette stubs; Table 1). The origin of many less numerous categories is not clear and probably reflects chance deposition. According to PCA, the northerly “dirtiest” sites Sanlúcar norte and Sanlúcar sur, close to the mouth of the major river Guadalquivir, unexpectedly, showed an abundance of recreational litter categories, but these may be either locally deposited or transported by river. The sheltered site Valdelagrana río, in particular is aligned with the industrial/commercial/fishing categories accumulating in the Bay. In contrast, Rota 
norte and Costa Ballena, located on the open coastline, appear to contain mainly recreational litter likely to be deposited on site.

\subsection{Management of cleaned beaches}

Although the major differences in beach litter between the surveyed sites were shown to be due to beach cleaning operations, multivariate analyses may reveal other patterns of litter distribution and abundance related to the sources and mode of deposition of items. Besides the clear “clean-versus-dirty” trend on PC1, vector plots for litter categories at all 20 beach sites (Figs. 4, 5) suggest differing origins of litter items as displayed on PC2. Hence categories PL51/PL11/PL45/ME24 (industrial packaging materials, large oil container, plastic fish box, large metal pieces; Table 1), apparently industrial sources, orientate in opposition to PL24/PP04/ME09/ME10/PL18 (cigarette stubs and packets, foil wrapping, food cans, drinking straws; Table 1), apparently recreational sources. These results do not indicate a simple north-south trend among the sites with respect to their accumulated litter items; instead the factor of cleaning management potentially obscures other effects such as closeness to litter source areas, morpho-dynamic state and level of exposure/shelter.

Barnes (2002) commented on the exponential growth of marine litter due to lack of management at source. In 1975 the annual influx rate of litter to the oceans was circa 6.4 million tonnes (National Academy of Sciences, 1975 and 2008), GBRMPA (2006) estimated it as 7 million tonnes, now 9 million tonnes per annum (www.statisticbrain). The bulk of this is composed of plastics, and Williams et al. (2013) have argued that the future must be centred on plastic chemistry changes, e.g. using the carbon neutral and biodegradable polylactic acid (PLA) as an alternative to petroleum based plastics; or a new biodegradable replacement made from the monomer gamma-butyrolactone, termed poly (GBL). This is equivalent to a polym (hydroxybutyrate) or P4HB, but cheaper to produce. Of note is the ECs recent announcement of the 2015 final economic policy which outlines a recycling target of $75 \%$ of packaging waste and a landfill target of $10 \%$ of all waste by 2030 , hopefully via the circular economy.

A detailed understanding of the problem is needed to manage effectively, and thereby mitigate marine litter impacts. Specifically it is important to determine the principal types and sources of marine litter, and to monitor the extent to which they change through time and with management interventions. The most cost-effective approach to reducing downstream environmental impacts should address the input processes (litter discards), by engaging 
industry, municipalities, regulatory authorities and the general public in an integrated way (Figure 10). Improvements involve waste management (disposal/recycling) facilities, port/harbour reception practices, beach user education (re domestic discards), combined with appropriate enforcement.

Litter issues severely threaten the "sun, sea and sand (3S)" industry, and effective beach management plans must aim to provide what tourists desire from a beach environment. Surveys carried out over many European beaches have shown that the beach environment provides some $80 \%$ of the enjoyment of the holiday (Williams and Micallef, 2009) and five beach parameters are of the greatest importance to coastal tourists: safety, facilities, water quality, litter and scenery, the weighting of each being a function of beach type (Williams and Micallef, 2009).

Over 20 years ago, Windom (1992) postulated that marine litter on tourist beaches would have the greatest negative economic impact on marine and coastal tourism, due to the reduction of amenity with degraded coastal areas Gregory (1999). Williams et al. (2000, 2016), Sheavely and Register (2007) pointed out that coastal communities rely on tourism: if the beach appearance is unacceptable due to litter, local income and municipality revenues are severely reduced. This is the prime motivation for clean-up incentives. Morgan et al. (1995), Ofiara (2001), Mcllgorm et al. (2011), and Jang et al. (2014) have all confirmed such findings, so planners/managers have a duty to address this issue.

Although prevention at source is the key to marine litter reduction (Figure 10), many types originate outside a beach area, being transported in by currents and deposited by waves. A beach manager can do little to resolve such external sources, yet he/she has the responsibility to remove it from the beach - a mandatory task in many resort/urban beaches. To the local manager, discarded recreational litter is a major concern and this represents a huge cultural problem, for which the ultimate solution is education. Achieving such a shift in attitude may be possible, as evidenced by the respect that Australians, for example, have for their beach culture.

An alternative approach of policing is adopted in Singapore, where harsh treatment is given to litterers. Penalties exist for littering in Spain, but implementation is very poor and in practice the law is rarely enforced. Three levels of fines exist - low, €100 to 750 (for leaving litter on the beach); high, €751 to 1.500 (for leaving 'cutting' litter e.g. glass); and very high, $€ 1.501$ to 3.000 (for dangerous items, e.g. munitions, etc.). Recently, SAS (2014) proposed 
European legislation to enforce fines for beach littering, and to promote responsible behavioural changes, for example, by banning beach smoking. On Cádiz beaches in 2013, the Municipality freely provided 3,000 cones at sun loungers for beach users who smoke.

To manage litter, a reliable measurement methodology is essential and examples of survey methods are given in this paper. Beach clean-up operations are admirable but are invariably carried out by committed environmentally-minded volunteers, whereas there is a need to reach out and recruit a wider audience. If sufficient numbers of suitable litter bins are available, the task of cleaning beaches is made much simpler and quicker. Excellent litter bins that sort our various litter categories (plastics, cans, etc.) can be seen found in Malta (Figure 11a); a Spanish example is given in Fig 11b. As can be seen it is small and the distance between bins is very large for a beach that is densely populated during the summer period.

\section{CONCLUSIONS}

- Most beaches along the coastline around Cádiz are in an acceptable condition and receive heavy tourist usage not only in summer time but also in spring, autumn and often in winter because of generally good weather conditions. Urban beaches are used as recreational areas throughout the year for walking, sports, etc.

- As a consequence, recreational beaches need to be cleaned more frequently (including spring time), despite the consequent increase in beach maintenance costs.

- Beach cleaning operations greatly reduce the quantity of litter, despite being inefficient at removing small items such as glass fragments and cigarette stubs.

- It is likely that beach grading could be improved by relatively little additional cleaning operations at some sites.

- A wide variety of litter categories was present at the non-cleaned sites, the most frequent being plastic, metal and foil food and drink containers together with plastic fragments.

- Litter items originating from industrial/commercial (transported onto site but originating elsewhere, e.g. Valdelagrana río), as opposed to domestic/recreational sources (discarded locally by visitors/residents e.g. Sanlúcar norte and Rota norte), 
occur mainly at different beach sites, depending on the patterns of use at the site and its location.

- The relative abundance of litter categories differed between exposed beaches (open coastline) with mainly recreational litter, as opposed to sheltered locations (bay, river or tidal creek) with mainly industrial-sourced litter and floating items transported in.

- Surveys of beach litter have focused on the Mediterranean coastline; hence more work is needed on Spanish Atlantic coastal sites to identify litter sources and improve the cost-effectiveness of beach maintenance.

\section{ACKNOWLEDGEMENTS}

This work is a contribution to the research group "RNM-328” (Andalusia, Spain). Special thanks go to Daniel García Jiménez, Environmental Branch of Cádiz Municipality, Spain. The excellent suggestions of unknown reviewers added greatly to the content of the paper.

\section{REFERENCES}

Álvarez O., Izquierdo A., Tejedor B., Mañanes R., Tejedor L., Kagana B.A. 1999. The Influence of Sediment Load on Tidal Dynamics, a Case Study: Cádiz Bay. Estuarine, Coastal and Shelf Science, 48: 439-450.

Anfuso G., Gracia F.J. 2005. Morphodynamic Characteristics and Short-Term Evolution of a Coastal Sector in SW Spain: Implications for Coastal Erosion Management. Journal of Coastal Research, 21 (6): 1139-1153.

Ariza E., Jiménez J.A, Sardá R. 2008a. A critical assessment of beach management on the Catalan coast. Ocean \& Coastal Management, 51: 141-160.

Ariza E., Jimenez J.A., Sarda R. 2008b. Seasonal evolution of beach waste and litter during the bathing season on the Catalan coast. Waste Management, 28: 2604-2613.

Barnes D.K.A. 2002. Invasions by marine life on plastic debris. Nature, 416: 808-809.

Browne M.A., Crump P., Niven S.J. 2011. Accumulation of microplastic on shorelines worldwide: sources and sinks. Environ. Sci. Technol., 45: 9175-9179.

Cheshire A.C., Adler E., Barbière J., Cohen,Y., Evans S., Jarayabhand S., Jeftic L., Jung R.T., Kinsey S., Kusui E.T., Lavine I., Manyara P., Oosterbaan L., Pereira M.A., Sheavly S., Tkalin A., Varadarajan S., Wenneker B., Westphalen G. 2009. UNEP/IOC Guidelines 
on Survey and Monitoring of Marine Litter. UNEP Regional Seas Reports and Studies, No. 186; IOC, Technical Series No. 83: xii + 120 pp.

Cochran W.G. 1977. Sampling Techniques (3rd edition), Wiley, 428 pp.

Coe J.M., Rogers D.B. (eds.) 1997. Marine debris: Sources, impacts and solutions. SpringerVerlag, New York, NY, USA.

Corral C., Ruiz C., Aula Marina “El Terrón”, Aula del Mar de Málaga, Red CoastWatch Andalucía (2007). Cuidemos la Costa 2005-2006, Sevilla: Consejerías de Medio Ambiente y Educación, Junta de Andalucía, 59 pp.

Dixon T., Dixon, T. 1981. Marine litter surveillance. Marine Pollution Bulletin, 12 (9): 289295.

Dixon T., Hawksley, C. 1980. Litter on the beaches of the British Isles. Report of the First National Shoreline Litter Survey. Sponsored by The Sunday Times. Marine Litter Research Programme, Stage 3, The Tidy Britain Group. 70pp.

Dubsky K. (Ed). 1995. CoastWatch Europe. Results of the International 1994 Autumn Survey. ISBN 0-9523324-6-9. CoastWatch Europe. 128pp.

EA/NALG. 2000. Environment Agency and the National Aquatic Litter Group. Assessment of Aesthetic Quality of Coastal and Bathing Beaches. Monitoring Protocol and Classification Scheme, 15 pp.

Earll R.C. 1996. Measuring and managing litter in rivers, estuaries and coastal waters. A guide to methods. Working document. (ed.), R. Earll, M. Everard, N. Lowe, C Pattinson and A. T. Williams. 78pp.

Gabrielides G.P., Golik A., Loizides L., Marino, M.G., Bingel F., Torregrossa M.V. 1991. Man-made garbage pollution on the Mediterranean coastline. Marine Pollution Bulletin, 23: 437-441.

Galgani F., Leaute J.P., Moguedet P., Souplet A., Verin Y., Carpentier A., Goraguer H., Latrouite D., Andral B., Cadiou Y., Mahe J.C., Poulard J.C., Nerisson P. 2000. Litter on the sea floor along European coasts. Marine Pollution Bulletin, 40: 516-527.

GBRMPA 2006. Litter. Great Barrier Reef Marine Park Authority. Fact Sheet No17 August.

Gilligan M.R., Pitts R.S., Richardson J.P., Kozel T.R. 1992. Rates of accumulation of marine debris in Chatham County, Georgia. Marine Pollution Bulletin, 24 (9): 436-441.

Gregory M.R. 1999. Plastics and South Pacific Island shores: environmental implications. Ocean and Coastal Management, 42: 603-615. 
Gregory M.R. 2009. Environmental implications of plastic debris in marine settings, dentanglement, ingestion, smothering, hangers-on, hitch-hiking and alien invasions. Philos. Trans. Royal Soc. B, 364: 2013-2025.

Hong S., Lee J., Jang Y.C., Kim Y.J., Kim H.J., Han D., Hong S.H., Kang D, Shim, W.J. 2013. Impacts of marine debris on wild animals in the coastal area of Korea. Marine Pollution Bulletin, 66: 117-124.

Jang Y.C., Hong S., Lee J., Lee M.J., Shim, W.J. 2014. Estimation of lost tourism revenue in Geoje Island from the 2011 marine debris pollution event in Korea. Marine Pollution Bulletin, 81: 49-54.

Jurado V., Castro M., Corral C., Ruiz C., Lara R., Acosta J., Macías A., Gracia J. 2006. Cuidemos la Costa 2004-2005. Red CoastWatch, Sevilla: Consejerías de Medio Ambiente y Educación, Junta de Andalucía. 64 pp.

Kauffman J., Brown M. 1991. California marine debris action plan. (In), Coastal Zone '91. (eds.). Magoon, O.T., Converse, H., Tippie, V., Tobin, L.T. and Clark, D. Proceedings of the Seventh Symposium on Coastal and Ocean Management. Long Beach, California, July 8-12, 1991. 3390-3406.

Martinez-Ribes L., Basterretxea G., Palmer M., Tinetorè J. 2007. Origin and abundance of beach debris in the Balearic Islands. Scientia Marina, 71 (2): 305-314.

Masselink G., Short A.D. 1993. The effect of tide range on beach morphodynamics and morphology: a conceptual beach model. Journal of Coastal Research, 9: 785 - 800.

Mcllgorm A., Campbell H.F., Rule M.J. 2011. The economic cost and control of marine debris damage in the Asia-Pacific region, Ocean \& Coastal Management, 54: 643-651.

Moore S.L., Gregorio D., Carreon M., Weisberg S.B., Leecaster MK. 2001. Composition and distribution of beach debris in orange County, California. Marine Pollution Bulletin, 42: $241-245$.

Morgan R., Bursahoglu B., Hapoglu-Balas L., Jones T.C., Ozhan E., Williams A.T. 1995. Beach user opinions and beach ratings: A pilot study on the Turkish Aegean coast. (In): Proceedings of the Second International Conference on the Mediterranean Coastal Environment. MedCoast 95, (ed.), E. Ozhan. 373-383.

National Academy of Sciences 1975. Assessing Potential Ocean Pollutants. A report of the Study Panel on Assessing Potential Ocean Pollutants to the Ocean Affairs Board Commission on Natural Resources National Research Council. Chapter 8 pp 405-431. 
National Academy of Sciences, 2008. Marine Debris Will Likely Worsen In The 21st Century. Science-Daily. http://www.sciencedaily.com/releases/2008/09/080919142602.htm, accessed October 2014.

NOAA Marine Debris Shoreline Survey Field Guide, 2012. Sarah Opfer, Courtney Arthur, and Sherry Lippiatt, 19pp

Ofiara D.D. 2001. Assessment of the economic losses from marine pollution: an Introduction to economic principles and methods. Marine Pollution Bulletin, 42 (9): 709 -725.

Oigman-Pszczol S.S, Creed J.C. 2007. Quantification and classification of marine litter on beaches along Armaçao dos Búzios, Rio de Janeiro, Brazil. Journal of Coastal Research, 23 (2): 421-428.

Olin R., Carlsson B., Stahre B. 1994. The west coast of Sweden - the rubbish tip of the North Sea. (In), Coastal and Riverine Litter: Problems and Effective Solutions, (ed.), R Earll, Marine Environmental Management and Training, Kempley, Glos., UK. 12-14.

OSPAR 1995. Summary Record of the Oslo and Paris Conventions for the Prevention of Marine Pollution, Working Group on Impacts on the Marine Environment (IMPACT) Group, IMPACT 95/14/1-E.

OSPAR 2009. Marine Litter in the North-East Atlantic Region: Assessment and priorities for response. London, United Kingdom, $127 \mathrm{pp}$.

Philipp R. 1993. Community needlestick accidents and trends in environmental quality. Public Health, 107: 363-369.

Rangel Buitrago N., Anfuso G. 2011. Coastal storm characterization and morphological impacts on sandy coasts. Earth Surface Processes and Landforms, 36: 1997-2010.

Rangel Buitrago N., Anfuso G. 2013. Winter wave climate, storms and regional cycles: the SW Spanish Atlantic coast. International Journal of Climatology, 33: 2142-2156.

Ribic A.C., Dixon T.R., Vining I. 1992. Marine debris survey manual, NOAA Technical Report. NMFS 108, US Department of Commerce. 92 pp.

Ribic C.A. 1998. Use of indicator items to monitor marine debris on a New Jersey beach from 1991-1996, Marine Pollution Bulletin, 36 (11): 887-891.

Roca E., Villares M., Ortego M.I. 2009. Assessing public perceptions on beach quality according to beach users' profile: A case study in the Costa Brava (Spain). Tourism Management, 30 (4): 598-607.

Santos I.R., Friedrich A.C., do Sul J.A.I. 2009. Marine debris contamination along undeveloped tropical beaches from northeast Brazil. Environ. Monit. Assess., 148: 455462. 
SAS 2014, Suffers against Sewage, Marine litter report. - 2020 vision.

Schulz M., Neumann D., Fleet D.M., Matthies M. 2013. A multi-criteria evaluation system for marine litter pollution based on statistical analyses of OSPAR beach litter monitoring time series. Mar. Environ. Res., 92: 61-70.

Sheavly S.B., Register K.M. 2007. Marine debris and plastics: Environmental concerns, sources, impacts and solutions. Journal of Polymers and the Environment, 15: 301-305.

Silva-Iñiguez L., Fisher D.W. 2003. Quantification and classification of marine litter on the municipal beaches of Ensenada, Baja California. Marine Pollution Bulletin, 46 (1): 132138.

Simmons S.L., Williams A. T. 1997. Qualitative versus quantitative litter data analysis. (In), Proceedings of the Third International Conference on the Mediterranean Coastal Environment, MEDCOAST 97. (Ed), Özhan, E. 397-406.

Smith V.K., Zhang X., Palmquist R.B. 1997. Marine debris, beach quality, and nonmarket values. Environ. Resour. Econ., 10: 223-247.

Somerville S.E., Miller K.L., Mair J.M. 2003. Assessment of the aesthetic quality of a selection of beaches in the Firth of Forth, Scotland. Marine Pollution Bulletin, 46: 11841190.

Taffs K.H., Cullen M.C. 2005 The distribution and abundance of beach debris on isolated beaches of Northern New South Wales, Australia. Australian Journal of Environmental Management, 12: 244-250.

Thiel M., Hinojos I.A., Miranda L., Pantoja J.F., Rivadeneira M.M., Vásquez N. 2013. Anthropogenic marine debris in the coastal environment: a multi-year comparison between coastal waters and local shores. Marine Pollution Bulletin, 71: 307-316.

Tudor D., Williams A.T. 2004. Development of a 'Matrix Scoring Technique' to determine litter sources at a Bristol Channel beach. Journal of Coastal Conservation, 9: 119-127.

Tudor D.T., Williams A.T., Randerson P., Ergin A., Earll R. 2002. The use of multivariate statistical techniques to establish beach debris pollution sources. Journal of Coastal Research, 36: 716-725.

UNEP 2011. Plastic debris in the ocean. Emerging issues in our global environment.

Valle-Levinson A., Swanson R.L. 1991. Wind-induced scattering of medically-related and sewage-related flotables. Marine Technology Society Journal, 25 (2): 49-56.

van Franeker J.A., Blaize C., Danielsen J., Fairclough K., Gollan J., Guse N., Hansen P.-L., Heubeck M., Jensen J.K., Le Guillou G., Olsen B., Olsen K.O., Pedersenm J., Stienen 
E.W.M., Turner D.M. 2011. Monitoring plastic ingestion by the northern fulmar Fulmarus glacialis in the North Sea. Environ. Pollut., 159: 2609-2615.

Velander K.A, Mocogni M. 1998. Maritime litter and sewage contamination at Cramond Beach, Edinburgh: a comparative study. Marine Pollution Bulletin, 36: 385-389.

Votier S.C., Archibald K.., Morgan G., Morgan L. 2011. The use of plastic debris as nesting material by a colonial seabird and associated entanglement mortality. Marine Pollution Bulletin, 62: 168-172.

Whitting S. 1998. Types and Sources of Marine Debris in Fog Bay, Northern Australia, Marine Pollution Bulletin, 36 (11): 904-910. Tudor, D.T., and A.T., Williams. 2001. Transect size and other threshold levels in beach litter measurement. Shore and Beach, Vol. 69 (4), 13-18.

Williams A.T., Randerson R., Alharbi O. 2014. From a Millennium base line to 2012: Beach litter changes in Wales. Marine Pollution Bulletin, 84: 17-26.

Williams A.T., Rangel Buitrago N., Anfuso G., Cervantes O., Botero C. 2016. Litter impacts on scenery and tourism on the Colombian north Caribbean coast. Tourism Management, 55: 1-16.

Williams A.T., Pond K., Ergin A., Cullis M.J. 2013. The hazards of beach litter (in) Coastal Hazards, (ed.), Charles Finkl, 753-780, Springer.

Williams A.T., Simmons S.L. 1997. Estuarine litter at the river/beach interface. Journal of Coastal Research, 13 (4): 1159-1165.

Williams A.T., Tudor T.D. 2001. Temporal trends in litter dynamics at a pocket beach. Journal of Coastal Research, 17 (1): 137-145.

Windom H.L. 1992. Contamination of the marine environment from land based sources. Marine Pollution Bulletin, 25 (1-4): 32-36.

Woodall P.F. 1993. Marine litter on the beaches of Deepwater National Park, central Queensland. QId. Nat., 32: 72-75.

Wright L.D., Short A.D. 1984. Morphodynamic variability of beaches and surfzones: A synthesis. Marine Geology, 56: 92-118.

www.statisticbrain.com/littering-statistics/ (accessed October 2015).

www.andalucia.org/media/tinyimages/file/perfil_prof_cadiz_dic14.pdf, (accessed February 2015). 


\section{FIGURE CAPTIONS}

Figure 1. Selected beaches. Key to beach names and codes with 'cleaned' and 'non-cleaned' beaches respectively in white and black colours (in figure) and in normal and bold/italic fonts respectively in legend: 1 Sanlúcar norte (SanIN); 2 Sanlúcar sur (SanIS); 3 Chipiona norte (ChipN); 4 Chipiona sur (ChipS); 5 Costa Ballena (CostB); 6 Rota norte (RotaN); 7 Rota centro (RotaC); 8 Rota sur (RotaS); 9 El Puerto de Santa Maria norte (SMarN);10 El Puerto de Santa Maria centro (SMarC); 11 El Puerto de Santa Maria sur (SMarS); 12 Valdelagrana norte (ValdN); 13 Valdelagrana sur (ValdS); 14 Valdelagrana rio (ValdR); 15 Puerto Real (PuerR); 16 Playa de Santa Maria, Cadiz (PlaSM); 17 Playa Victoria, Cadiz (PlayV); 18 Camposoto norte (CampN); 19 Camposoto sur (CampS); 20 Camposoto rio (CampR).

Figure 2. Cluster dendrogram for 20 Sites (59 categories; non-standardized). For site codes refer to Figure 1.

Figure 3. PCA scatter-plot for 20 Sites (59 categories; non-standardized). For site codes refer to Figure 1.

Figure 4. PCA vector-plot for 59 categories (20 Sites; non-standardized). For category codes refer to Table 1.

Figure 5. PCA vector-plot for 59 categories (20 Sites; standardized). For category codes refer to Table 1. Note: the polarity of PCs is arbitrary, only the relative positions of vectors are important.

Figure 6. Cluster dendrogram for 7 non-cleaned Sites (49 categories; non-standardized). For site codes refer to Figure 1. Site locations and numbers of litter items per site are shown.

Figure 7. PCA scatter-plot for 7 non-cleaned Sites (49 categories; non-standardized). For site codes refer to Figure 1. Site locations and numbers of litter items per site are shown.

Figure 8. PCA vector-plot for 49 categories (7 Sites; non-standardized). For category codes refer to Table 1.

Figure 9. PCA vector-plot for 49 categories (7 Sites; standardized). For category codes refer to Table 1.

Figure 10. Management Issues.

Figure 11. a) Litter bin in Malta; b) Litter bin in Cádiz (i.e. 16 Playa de Santa María), Andalusia. 


\section{TABLES}

Table 1. Category codes for litter items in the 20-site survey. Categories which occurred only in cleaned beaches are shown by *.

Table 2. EA/NALG (2000) Beach grading system based on selected categories of litter. Grading: A Very good; B Good; C Fair, D Poor.

Table 3. Numbers of Hazardous litter items found. Shading indicates hazard-free beach sites. Site numbers relate to Figure 1 with “non-cleaned” beaches in bold/italic.

Table 4. EA/NALG (2000) grading of non-cleaned beaches. Site numbers relate to Fig. 1. Shading indicates final grade achieved.

Table 5. EA/NALG (2000) grading of cleaned beaches. Site numbers relate to Fig. 1. Shading indicates final grade achieved. 